Allen, M. C., J. Burger and J. L. Lockwood. 2019. Evaluation of unharvested refugia for grassland bird conservation within active hayfields. Avian Conservation and Ecology 14(2):15. https://doi.org/10.5751/ACE-01457-140215

Copyright (C) 2019 by the author(s). Published here under license by the Resilience Alliance.

Research Paper

\title{
Evaluation of unharvested refugia for grassland bird conservation within active hayfields
}

\author{
Michael C. Allen ${ }^{1}$, Joanna Burger ${ }^{1,2,3}$ and Julie L. Lockwood ${ }^{1}$ \\ ${ }^{1}$ Department of Ecology, Evolution, and Natural Resources, Rutgers, The State University of New Jersey, New Brunswick, NJ, \\ USA, ${ }^{2}$ Department of Cell Biology and Neuroscience, Rutgers, The State University of New Jersey, Piscataway, NJ, USA, \\ ${ }^{3}$ Environmental and Occupational Health Sciences Institute, Rutgers, The State University of New Jersey, Piscataway, NJ, USA
}

\begin{abstract}
Agricultural grasslands such as hayfields and pastures frequently act as ecological traps for grassland birds because of harvest practices that interfere with successful nesting. Conservation measures that improve reproductive success while allowing farmers to maintain agricultural outputs are needed to help stem widespread grassland bird population declines. We evaluated leaving uncut patches ("refugia") within harvested hayfields to provide cover, reduce field abandonment, and promote renesting by three grassland species: Bobolink (Dolichonyx oryzivorus), Grasshopper Sparrow (Ammodramus savannarum), and Eastern Meadowlark (Sturnella magna). In 2014-2016, we left five refugia (0.25 ha each) within a 23-ha hayfield in New Jersey, USA. We found refugia were used more relative to cut areas by Bobolink and Grasshopper Sparrow, but not by Eastern Meadowlark. The presence of refugia also appears to have reduced field abandonment following harvest in all three years for Bobolink and Grasshopper Sparrow when compared to two adjacent fields that lacked refugia. We observed territorial singing, but no evidence of renesting in refugia following harvest, though this may relate to the relatively late harvest dates (26 Jun-3 Aug). Response patterns were consistent over the three years of the study and suggest that leaving small refugia within active hayfields could be a valuable supplement to current management incentive approaches.
\end{abstract}

\section{Évaluation des refuges non récoltés pour la conservation des oiseaux des prairies au milieu de champs fauchés et exploités}

RÉSUMÉ. Les prairies agricoles comme les prés et les pâturages se transforment souvent en pièges écologiques pour les oiseaux des prairies. En effet, les pratiques de récolte perturbent leur nidification. Il est nécessaire de prendre des mesures de conservation visant à améliorer la reproduction des oiseaux tout en permettant aux agriculteurs de conserver leur productivité afin de remédier au déclin considérable des populations d'oiseaux des prairies. Nous avons évalué l'utilité des espaces sauvages (ou « refuges ») au milieu de prés cultivés afin de leur offrir un abri, de réduire l'abandon des champs et de promouvoir la renidification de trois espèces d'oiseaux des prairies : le goglu des prés (Dolichonyx oryzivorus), le bruant sauterelle (Ammodramus savannarum) et la sturnelle des prés (Sturnella magna). De 2014 à 2016, nous avons laissé cinq refuges (de 0,25 hectares chacun) dans un pré de 23 hectares dans le New Jersey, aux États-Unis. Nous avons constaté que le le goglu des prés et le bruant sauterelle préféraient les refuges aux zones entretenues, mais que ce n'était pas le cas de la sturnelle des prés. La présence de refuges semble également avoir réduit le taux d'abandon des champs par le goglu des prés et le bruant sauterelle suite à la récolte par rapport à deux champs adjacents où il n'y avait pas de refuge. Nous avons observé des chants territoriaux, mais aucune preuve de renidification dans les refuges suite à la récolte, même si cela pourrait être lié à des dates de récolte relativement tardives (du 26 juin au 3 août). Les modèles de réaction sont restés cohérents au cours des trois années de l'étude et suggèrent que le fait de laisser de petits refuges au sein de prés cultivés pourrait représenter un complément précieux aux approches actuelles de gestion incitative.

Key Words: agriculture; conservation; experiment; grassland birds; hayfield; mowing; private lands

\section{INTRODUCTION}

Grassland birds around the world are increasingly reliant on agricultural and other anthropogenic land uses, e.g., airports and landfills, where their population dynamics are tightly linked to management practices and economic concerns (Askins et al. 2007, Batáry et al. 2015, Dotta et al. 2016). Globally, over $70 \%$ of the land area in grassland biomes have been converted to agricultural uses, and the fraction is even higher in North America ( 83\%; Ramankutty et al. 2008, Dixon et al. 2014) where hay, pasture, and fallow fields now represent the dominant source of grassland bird habitat (Askins et al. 2007). In the first half of the 20th century, North America's agricultural landscapes supported thriving grassland bird populations, but subsequent trends toward production intensification and conversion to row crops have contributed to widespread population declines, raising the question of whether viable grassland bird populations are compatible with modern agriculture (Peterjohn 2003, Askins et al.2007). At the same time, conservation opportunities exist where grassland habitat is created and maintained as a byproduct of economic activity, e.g., hay production or airport maintenance,

Address of Correspondent: Michael C. Allen, Rutgers, the State University of New Jersey, 14 College Farm Rd, Floor 1, New Brunswick, New Jersey, USA 08901, mcallen@scarletmail.rutgers.edu 
leading to more total grassland in some regions than was historically present, e.g., the northeastern United States (Peterjohn 2003). With appropriate management, anthropogenic grasslands can be assets rather than liabilities for grassland bird populations (Bollinger et al. 1990, Perlut et al. 2008).

In northeastern North America, grassland birds normally arrive on the breeding grounds from mid-April to mid-May, and are actively nesting through June-August, depending on the species (Perlut et al. 2006, Jaster et al. 2012). Hayfields make up a large fraction of grasslands available to these species in northeast and mid-Atlantic states: an estimated 2.2 million ha in 13 states (U.S. Fish and Wildlife Region 5) in 2012, compared to 2.5 million ha of pastureland and $<0.3$ million ha of airport grasslands (DeVault et al. 2012, USDA 2012). Hay harvest typically occurs in June, the middle of the breeding season for most grassland birds and destroys nearly all nests active at the time of harvest (Bollinger et al. 1990, Luscier and Thompson 2009). Earlier and more frequent hay harvests over the past half-century are implicated in population declines of grassland bird species in the northeast (Bollinger et al. 1990, Troy et al. 2005, Perlut et al. 2008), and although renesting after harvest can occur, structural alteration and reduction in food resources cause some species to largely abandon fields or forego renesting opportunities for the season (Perlut et al. 2006, Luscier and Thompson 2009, Grüebler et al. 2015).

Conservation measures for grassland birds in hayfields have primarily focused on monetary compensation for farmers by federal, state, and nongovernmental groups to delay harvests and allow time for grassland birds to rear their broods, but funding limits these practices to a relatively small area in most eastern states (Troy et al. 2005; M. C. Allen, unpublished data). For example, Troy et al. (2005) report that $<1500$ ha were enrolled in such programs in Vermont in 2003, or less than $1 \%$ of total hayfield area in that state (USDA 2012). Both lack of funding and a lack of adoption by farmers likely contribute to the limited scope of the programs. Delaying harvest interferes with normal hay production as hay quality declines later in the season, leading to an inferior agricultural product (Nocera et al. 2005, Troy et al. 2005). A broader suite of practical, cost-effective conservation management measures would be useful for enhancing suitability of agricultural grassland habitats for birds, while maintaining the farm's economic sustainability and agricultural production levels. If farmers can maintain profits and receive additional payment incentives while still providing a benefit to birds, more farmers may adopt such practices.

Within-field conservation approaches for grasslands, i.e., interventions embedded within active agricultural fields, have gained traction recently, mainly in Europe, and especially for invertebrates (Buri et al. 2013, 2014, Garibaldi et al. 2014) and birds. For birds, these have included (1) finding individual nests and protecting them through agreements with farmers to avoid harming them with machinery (Koks and Visser 2002, Kragten et al. 2008, Grüebler et al. 2012), and (2) leaving patches or strips of standing crop to provide food and shelter for birds for the remainder of the season (Broyer 2003). The benefits of the former method, although labor intensive, are established (Musters et al. 2001), whereas the benefits of the latter are unknown for most species (but see Broyer 2003, Masse et al. 2008). Because some species are known to abandon fields and delay or avoid renesting following harvest (Owens and Myres 1973, Perlut et al. 2006, Grüebler et al.2015), it is especially relevant whether uncut refugia can provide enough food and cover for birds to remain on fields to renest and thus improve reproductive success. Delaying harvest in small patches or strips within hayfields is less expensive than entire fields, and thus the former has the potential to act as a lower cost, more-widespread supplement to the existing landscape of hayfield conservation incentive programs.

The goal of this study was to evaluate the utility of leaving uncut refugia in hayfields (Fig. 1) for promoting site persistence of three grassland bird species in eastern North America: Bobolink (Dolichonyx oryzivorus), Grasshopper Sparrow (Ammodramus savannarum), and Eastern Meadowlark (Sturnella magna). Specific objectives were to (1) compare bird use of refugia and harvested reference areas before and after harvest, and (2) evaluate the role of refugia in promoting site persistence and renesting following harvest. We hypothesized that some or all of these species would show greater use of refugia areas after the harvest and would also show lower rates of abandonment, i.e., maintain higher densities, in the field with refugia compared with completely harvested fields.

Fig. 1. An unharvested patch ("refugium") left for grassland birds in a central New Jersey (USA) hayfield, three days after the harvest.

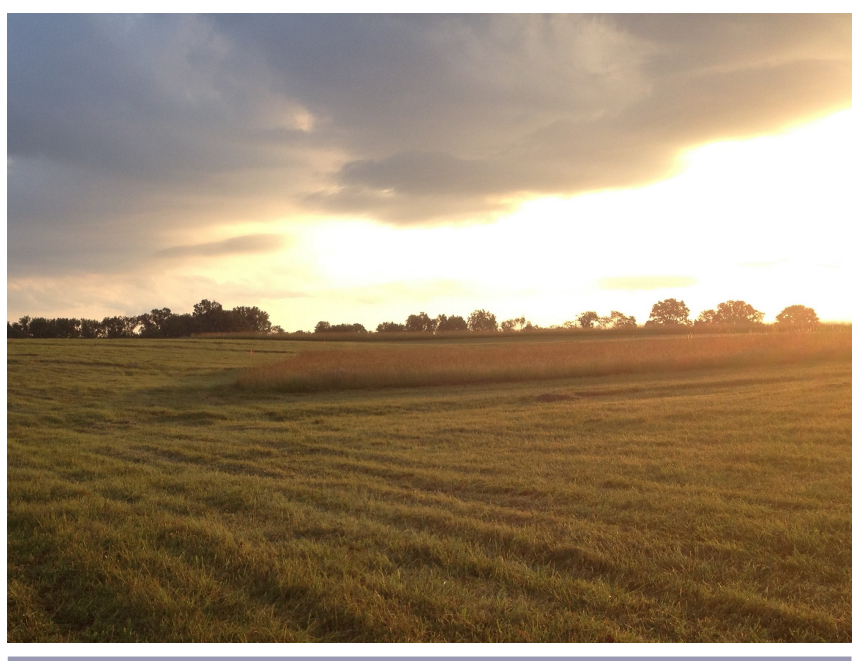

\section{METHODS}

Our study consisted of collecting data in three adjacent hayfields: a primary field in which we left rectangular unharvested areas, and two completely harvested nearby fields (named "north" and "south") used for comparison (Fig. 2). We performed four primary analyses: (1) a before-after-control-impact paired series (BACIPS; Conner et al. 2016) comparison of bird abundance in the rectangular unharvested patches (refugia) and paired harvested (reference) areas pre- and postharvest; (2) a postharvest evaluation of refugia usage, evaluating the effects of shape and time since harvest; (3) a comparison of field abandonment after harvest in the refugia-containing field with the two completely harvested fields; and (4) an analysis of the spatial and temporal 
Fig. 2. Experimental setup to test the value of uncut patches ("refugia") to grassland birds following harvest in a 23-ha hayfield in central New Jersey (USA), 2014-2016. White rectangles are refugia and gray rectangles are harvested reference areas used to compare relative bird abundance in a before-after-controlimpact paired series design. Black lines are 200-m bird survey transects established using the 200 x $200 \mathrm{~m}$ grid (light gray boxes). Two additional fields included in the study that lacked refugia ("north" and "south" fields) are located just beyond the tree lines from the primary field to the left and top of the map, respectively.

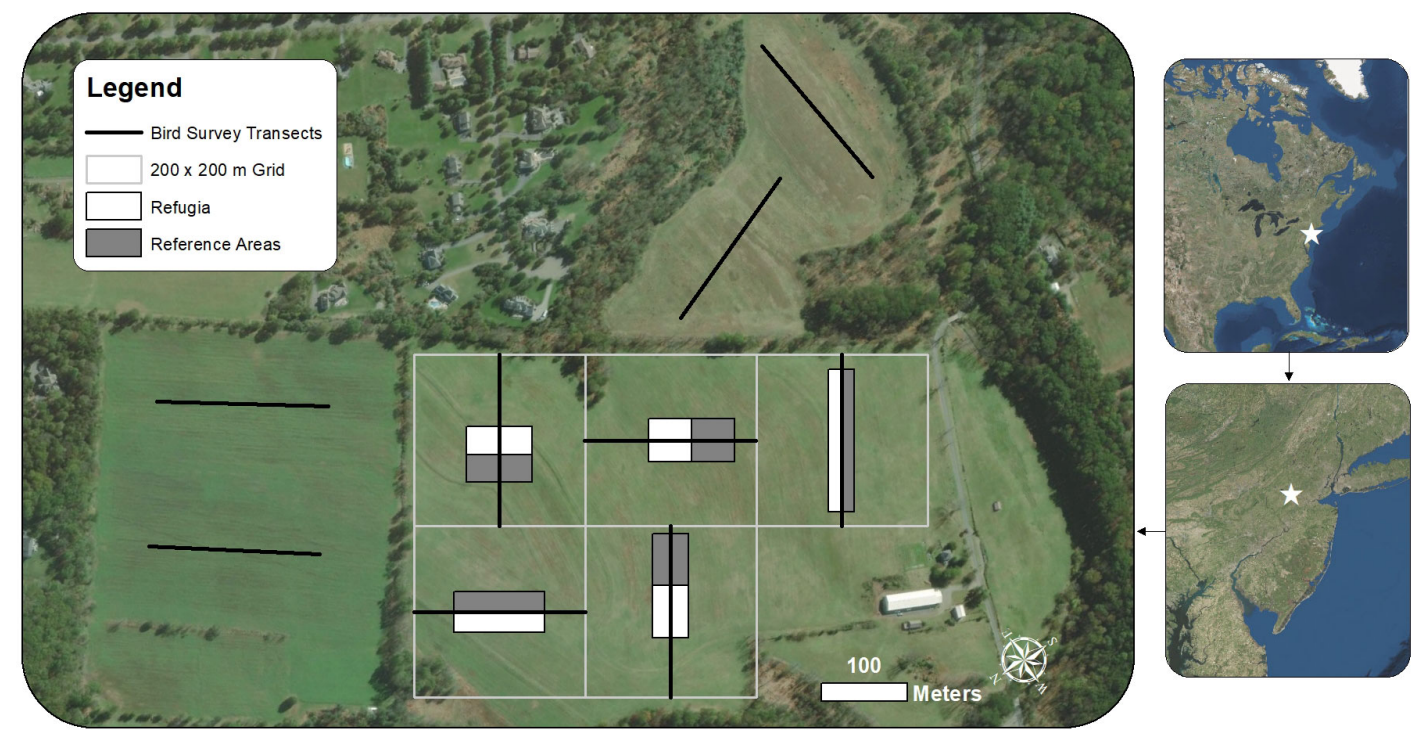

pattern of nest initiations in relation to refugia location and harvest timing.

\section{Study area}

The study took place May-August 2014-2016 in Hunterdon County, New Jersey, USA. This urbanizing agricultural region lies 30 miles west of New York City and is in the Piedmont physiographic province characterized by low, rolling topography. Land use is dominated by forest (42\%), agriculture (28\%), and developed land $(25 \%)$, while dominant field crops include hay $(61 \%)$, corn $(21 \%)$, and soybeans (12\%; USDA 2012, NJDEP 2015). The three hayfields studied were referred to as: primary (23 ha; $\left.40^{\circ} 34^{\prime} 26^{\prime \prime} \mathrm{N}, 74^{\circ} 45^{\prime} 47^{\prime \prime} \mathrm{W}\right)$, north (13 ha; $40^{\circ} 34^{\prime} 37^{\prime \prime} \mathrm{N}, 74^{\circ}$ $\left.45^{\prime} 36^{\prime \prime} \mathrm{W}\right)$, and south ( 8 ha; $\left.40^{\circ} 34^{\prime} 12^{\prime \prime} \mathrm{N}, 74^{\circ} 45^{\prime} 36^{\prime \prime} \mathrm{W}\right)$. The fields were adjacent (separated by tree lines; Fig. 2) and all contained a similar mix of fescue (Schedonorus sp.), orchard grass (Dactylis glomerata), little bluestem (Schizachyrium scoparium), vetch (Vicia sp.), and other less common species. Bobolink, Grasshopper Sparrow, and Eastern Meadowlark were the only grassland-obligate bird species nesting in the fields.

\section{Bird use of refugia}

We evaluated bird use in refugia and in paired reference areas before and after harvest using a BACIPS design (see Fig. 2). This experiment took place only in the primary field. The BACIPS design allowed us to measure treatment effects while controlling for local variation within the field (Conner et al. 2016). Five rectangular 0.25-ha refugia were designed in a geographic information system (GIS) ranging from square $(50 \times 50 \mathrm{~m})$ to increasingly narrow and elongated $(41 \times 61 \mathrm{~m}, 33 \times 77 \mathrm{~m}, 24 \times 105$ $\mathrm{m}$, and $15 \times 167 \mathrm{~m}$ ). Refugia area totaled 1.25 ha or $5 \%$ of the field. We sited refugia using a $200 \times 200 \mathrm{~m}$ grid overlaid on the field with a transect line bisecting each cell (Fig. 2). We randomly assigned refugia to a transect and positioned it along the line to allow identical coverage with a paired reference area. Refugia boundaries were marked in the field immediately prior to harvest using a handheld GPSMap 62s global positioning system (GPS; Garmin International, Olathe, Kansas, USA) and pink flagging. The farmer could mow around most corners and edges of the refugia with the large hay mower, but some corners and berm areas were "cleaned up" after the harvest with a smaller rotary mower adjusted to approximately the same height $(\sim 12 \mathrm{~cm})$. We used the same refugia locations in all three years. The farmers determined the harvest dates each year based on weather and other factors. The primary field was harvested 26 June 2014, 31 July-3 August 2015, and 5-6 July 2016. Refugia were mowed off between breeding seasons (Sep-Mar).

One observer (MCA) completed bird surveys along the transects twice per week, between $13 \pm 11$ (SD) and $149 \pm 26$ min after sunrise, from 15 May until early- to mid-August 2014-2016. The order and direction of surveys was alternated each time. The observer walked slowly $(19 \pm 3 \mathrm{~m} / \mathrm{min} \mathrm{SD})$, recording the following about each bird or group of birds to allow mapping and density calculations: species, number of individuals, GPS-derived Universal Transverse Mercator coordinates of the observer (accuracy $\sim 3-5 \mathrm{~m}$ ), distance using a laser rangefinder (accuracy $\pm \sim 0.5 \mathrm{~m}$ ), and compass bearing, adjusted for magnetic declination. We calculated densities within refugia and reference areas as the number of individuals per ha per survey based on mapped locations in a GIS. We excluded individuals classified as "fly-overs" or juveniles from analyses and lumped individuals of 
Table 1. Distance sampling analysis results for transect bird surveys conducted in three New Jersey (USA) hayfields, 2014-2016. Detection probabilities were estimated for the distance ranges present in each refugia $(0-15 \mathrm{~m}, 0-21 \mathrm{~m}, 0-24 \mathrm{~m}, 0-25 \mathrm{~m}$, and 0-38 m), as well as for the distance ranges $0-75 \mathrm{~m}$ and $0-100 \mathrm{~m}$ that were used to adjust field-level density estimates. The top-performing model based on Akaike information criterion is shown for each species/distance category. We evaluated nine models in each case, except for Grasshopper Sparrow (Ammodramus savannarum) and Eastern Meadowlark (Sturnella magna; $100 \mathrm{~m}$ truncation distance), which had sample sizes adequate to evaluate six additional models containing a covariate for pre- vs. postharvest (see Methods for details).

\begin{tabular}{|c|c|c|c|c|c|c|}
\hline Species & $\begin{array}{l}\text { Truncation } \\
\text { dist. }(\mathrm{m})\end{array}$ & $\begin{array}{c}\text { No. detections } \\
\text { (pre-/ postharvest) }\end{array}$ & Key function & $\begin{array}{l}\text { Adjustment } \\
\text { series }\end{array}$ & $\begin{array}{c}\text { Goodness-of-Fit } \\
\text { p-value }\end{array}$ & $\begin{array}{c}\text { Detection } \\
\text { probability }(\mathrm{SE})\end{array}$ \\
\hline \multirow[t]{7}{*}{ Grasshopper Sparrow } & 15 & $112(101 / 11)$ & Half-normal & Cosine & 0.73 & $0.716(0.109)$ \\
\hline & 21 & $144(127 / 17)$ & Uniform & Cosine & 0.63 & $0.792(0.071)$ \\
\hline & 24 & $159(141 / 18)$ & Uniform & Cosine & 0.63 & $0.786(0.066)$ \\
\hline & 25 & $165(147 / 18)$ & Uniform & Cosine & 0.60 & $0.795(0.066)$ \\
\hline & 38 & $242(215 / 27)$ & Half-normal & Cosine & 0.57 & $0.746(0.082)$ \\
\hline & 75 & $361(319 / 42)$ & Half-normal & Cosine & 0.48 & $0.640(0.030)$ \\
\hline & 100 & $377(324 / 53)$ & Half-normal & Cosine $e^{\dagger}$ & 0.36 & $0.484(0.021)$ \\
\hline \multirow[t]{7}{*}{ Bobolink } & 15 & $213(209 / 4)$ & Uniform & Simple Poly. & 0.63 & $0.967(0.072)$ \\
\hline & 21 & $272(268 / 4)$ & Uniform & Hermite Poly. & 0.71 & $0.861(0.054)$ \\
\hline & 24 & $300(296 / 4)$ & Uniform & Cosine & 0.74 & $0.817(0.054)$ \\
\hline & 25 & $309(305 / 4)$ & Uniform & Cosine & 0.77 & $0.809(0.051)$ \\
\hline & 38 & $441(436 / 5)$ & Uniform & Cosine & 0.64 & $0.831(0.045)$ \\
\hline & 75 & $688(671 / 17)$ & Uniform & Hermite Poly. & 0.38 & $0.697(0.019)$ \\
\hline & 100 & $763(743 / 20)$ & Uniform & Cosine & 0.32 & $0.593(0.014)$ \\
\hline \multirow[t]{7}{*}{ Eastern Meadowlark } & 15 & $32(18 / 14)$ & Uniform & Cosine & 0.86 & $1.000(0.238)$ \\
\hline & 21 & $38(21 / 17)$ & Uniform & Simple Poly. & 0.97 & $0.830(0.117)$ \\
\hline & 24 & $42(24 / 18)$ & Uniform & Simple Poly. & 0.99 & $0.817(0.106)$ \\
\hline & 25 & $43(24 / 19)$ & Uniform & Simple Poly. & 0.99 & $0.805(0.099)$ \\
\hline & 38 & $68(37 / 31)$ & Uniform & Cosine & 0.41 & $0.985(0.155)$ \\
\hline & 75 & $118(72 / 46)$ & Uniform & Simple Poly. & 0.53 & $0.807(0.062)$ \\
\hline & 100 & $144(89 / 55)$ & Uniform & Simple Poly. & 0.78 & $0.774(0.049)$ \\
\hline
\end{tabular}

Includes a pre- / postharvest covariate with a scale coefficient of -0.34 ( $0.17 \mathrm{SE})$ indicating greater detectability in harvested areas.

both sexes because they were not always possible to distinguish. For example, by late July, many male Bobolinks have molted into female-like plumage.

Imperfect detection could bias our results, especially if detection probability for a species changes in refugia and reference areas unequally following the harvest. For example, if relative detectability decreases in cut areas, e.g., because of behavioral differences, then refugia preference could be overestimated; if, however, lack of vegetation makes it easier to see birds then not accounting for detection probability may have the opposite effect. Distance sampling can correct for these biases, but no individual refugium in our study had the recommended minimum sample size of 60-80 detections to estimate a detection function (Buckland et al. 1993). Pooling data from within all refugia and reference areas was not possible because of the differing truncation distance required for each. Therefore, to learn more about potential detection biases, we evaluated changes in detection probability pre- vs. postharvest in the broader study area, i.e., the primary, north, and south fields. We excluded detections in or behind refugia because these features could cluster birds nonrandomly with respect to transect lines (see Fig. 2). We evaluated detection probability for each species in the $\mathrm{R}$ package "Distance" (Miller et al. 2019) at seven truncation distances: 15 m, $21 \mathrm{~m}, 24 \mathrm{~m}, 25 \mathrm{~m}, 38 \mathrm{~m}, 75 \mathrm{~m}$, and $100 \mathrm{~m}$. These represented the distance ranges within each of the five refugia plus two "upper bound" distance ranges $(75 \mathrm{~m}$ and $100 \mathrm{~m})$ used to estimate fieldlevel densities. All analyses included group size as a covariate. Sample sizes in all postharvest groups were still below 60 detections (Table 1) but were closest for Grasshopper Sparrow and Eastern Meadowlark (truncation distance of $100 \mathrm{~m}$ ), which had 53-55 detections. We therefore evaluated a set of nine models (all combinations of key functions and adjustment series in Miller et al. 2019) with no pre/postharvest covariate for most species and distance ranges. Model sets for Grasshopper Sparrow and Eastern Meadowlark (100 $\mathrm{m}$ truncation) included an additional six models (based on the half-normal and hazard-rate models) with a pre/postharvest covariate. For all sets, we selected a top model based on AIC and evaluated it based on the Cramer-von Mises goodness-of-fit test (alpha $=0.05$ ) as well as effect sizes and standard errors.

We adjusted densities within each refugium and reference area using detection probabilities from the top-performing model within the model set corresponding to the appropriate truncation distance (Table 1). We believe that our inability to correct for imperfect detection based on harvesting status did not strongly influence results because (1) detection probabilities were relatively high at all within-refugia distance ranges (0.72-1.00); and (2) we found little evidence for strong or consistent effects of hay harvests on detectability where sufficient data existed, i.e., Grasshopper Sparrow and Eastern Meadowlark at 0-100 m; see Results, Table 1. A parallel analysis (not presented here) using uncorrected densities produced identical conclusions.

The difference in corrected density estimates between paired refugia and reference areas during each survey served as the dependent variable in our refugia usage (BACIPS) analysis (Conner et al. 2016). These data were calculated from a subset of 
the biweekly survey data centered on the harvest date for each year: 12 weeks of data (i.e., 12 pre- and 12 postharvest surveys) in 2014 and 2016, and six weeks of data (6 pre- and 6 postharvest surveys) in 2015 because of a later harvest (31 Jul-3 Aug). We used repeated-measures linear mixed models to test for the fixed effects of year and time period (pre- or postharvest), and a random effect of transect (R package "Ime4"; Bates et al. 2015). We then ran identical models on refugia and reference area densities separately to determine if differences observed were due to a change in abundance within refugia, reference areas, or both. Effect sizes were evaluated based on fixed-effect coefficients with bootstrapped $95 \%$ confidence intervals ( 10,000 iterations), as well as conditional F-tests with Kenward-Roger-corrected degrees-offreedom (Bates et al. 2015). An alpha level of 0.05 was used for all tests.

\section{Refugia postharvest dynamics}

In 2014 and 2016, both of which had six weeks of postharvest transect bird surveys, we investigated if there was an increase or attenuation of refugia usage with time following the harvest, as well as if the magnitude of postharvest usage varied based on patch shape. We used general linear models (function " $1 \mathrm{~m}$ "; R Core Team 2017) with the dependent variable being the difference between paired refugia and reference areas at each transect averaged by week during the postharvest period. Independent variables were (1) days since harvest, (2) length:width ratio of refugia, and (3) year (2014 or 2016).

\section{Postharvest field abandonment}

To examine postharvest field abandonment, we performed transect bird surveys in the two completely harvested adjacent fields (north and south fields; Fig. 2) with the same time schedule and protocol as in the primary field. The north field was harvested 16 July 2014, 31 July 2015, and planted to row crops in 2016. The south field was harvested 21 July 2014, 6 August 2015, and 24 27 July 2016. If refugia served to prevent abandonment, we expected to see greater reductions in field-level densities after harvest in the fields lacking refugia. We established two 200-m transects in each field, positioned to provide maximum coverage: $77 \%$ of the north field and $100 \%$ of the south field were within $100 \mathrm{~m}$ of the transect lines.

We calculated field-level density as the average number of individuals observed per hectare of grassland per survey at two different extents: $0-75 \mathrm{~m}$ and $0-100 \mathrm{~m}$ perpendicular to the transect lines. This allowed us to evaluate the effect of the amount of area surveyed on resulting density estimates. As above, we excluded juveniles and fly-overs and lumped both sexes together for this analysis. We corrected for imperfect detection by dividing densities by species-specific detection probabilities derived from the corresponding $(0-75 \mathrm{~m}$ or $0-100 \mathrm{~m})$ distance sampling analysis discussed above (Table 1). Density estimates based on the $0-75 \mathrm{~m}$ and $0-100 \mathrm{~m}$ analyses were very similar (Pearson's $\mathrm{r}=0.99$; mean difference $=0.01$ ). Therefore, we used the broader $100 \mathrm{~m}$ area to examine field-level abandonment patterns postharvest.

\section{Nesting phenology and harvest impact on nests}

We searched for nests in the primary (2014-2016) and north (2014-2015) fields during daylight hours, usually 0500-0900 h and 1500-1900 h (EST) to reduce heat stress on eggs or young. We walked parallel transects through the field at a spacing of 10 $\mathrm{m}$ apart weekly from 15 May to 22-23 July, guided by a GPS, and agitating vegetation with a $2-\mathrm{m}$ stick to locate nests by flushing incubating females (Winter et al. 2003). The search path was shifted by $5 \mathrm{~m}$ in alternate weeks, with the effect of covering the entire area at $5 \mathrm{~m}$ spacing in each two-week period. We also looked for food-carrying behavior of adults and found nests by watching as they fed nestlings (this was also done during transect abundance surveys, which extended into early- to mid-Aug). We obtained GPS coordinates of nests and checked them every $1-3 \mathrm{~d}$ to determine contents, stage, and outcome.

We classified nests as either (1) inside or outside of refugia in a GIS, and (2) initiated pre- or postharvest based on phenology. We estimated the date of initiation (first day of incubation) for each nest by back-dating from the estimated hatch date or forwarddating for nests found during egg laying (assuming one egg laid per day). This date was then used to estimate a first egg date and a projected fledge date for each nest. We assumed incubation and nestling periods of 12 and $10 \mathrm{~d}$ for Bobolink, 12 and $9 \mathrm{~d}$ for Grasshopper Sparrow, and 13 and $11 \mathrm{~d}$ for Eastern Meadowlark (Vickery 1996, Jaster et al. 2012, Renfrew et al. 2015).

\section{RESULTS}

\section{Bird use of refugia}

Detection probabilities were $0.72-1.00$ for all species at distance ranges corresponding with refugia and reference areas $(0-15$ to $0-38 \mathrm{~m})$. These values were somewhat lower at $0-75 \mathrm{~m}(0.64-0.81)$ and $0-100 \mathrm{~m}(0.48-0.77$; Table 1$)$. We found little evidence of a strong or consistent effect of hay harvesting on detectability for the two species examined. For Grasshopper Sparrow (100 m truncation), the top model included the pre- vs. postharvest covariate (scaling coefficient: -0.338 [0.168 SE]; top model without covariate: $\triangle \mathrm{AIC}=2.10)$. Models predicted higher detectability in harvested than unharvested fields $(0.62$ [0.07] vs. $0.52[0.04]$ ). As an illustration, applying these detection probabilities to a count of 4 individuals would yield corrected estimates of 7.7 and 6.5, respectively. The best-performing model for Eastern Meadowlark (100 m truncation) lacked a pre/ postharvest covariate, though it ranked not far above a model that did contain the covariate $(\triangle \mathrm{AIC}=1.50)$. Contrary to results for Grasshopper Sparrow, this model predicted a trend of higher detection probability in unharvested grass $(0.81$ [0.09] vs. 0.69 [0.08]), though the standard error for the scale coefficient was high (0.310 [0.350]; C.V. $=94 \%)$.

The relative use of refugia, i.e., density in refugia minus reference areas, increased from pre- to postharvest for Bobolink (3-yr mean difference: 0.41 to 6.42 individuals/ha) and Grasshopper Sparrow (0.37 to 4.31 ), but not for Eastern Meadowlark ( -0.03 to 0.06 ; Table 2, Fig. 3). Supporting these patterns, confidence intervals of "time period" coefficient estimates from mixed effect models did not overlap zero for Bobolink $\left(\beta_{\text {pre vs. post }}=-6.70[95 \% \mathrm{C}\right.$. I. $=-10.87,-2.44]$ ) or Grasshopper Sparrow, $\beta=-3.61$ $[-4.60,-2.63])$, but widely overlapped zero for Eastern Meadowlark ( $\beta=0.10$ [-0.53, 0.72]; Table 3). Relative use of refugia also varied by year for Grasshopper Sparrow, with lower values in 2014 compared with 2015 and 2016 (Table 3, Fig. 3). 
Table 2. Mean density (individuals / ha) of grassland birds within refugia and reference areas in a central New Jersey (USA) hayfield before and after harvest. Average values of biweekly counts performed at the five transects ( $n=60$ per transect) were computed for the pre- and postharvest periods each year; these values were then adjusted for imperfect detection (see Table 1) averaged across transects to get the reported means $(\mathrm{SE} ; \mathrm{n}=5$ transects).

\begin{tabular}{|c|c|c|c|c|c|}
\hline \multirow[b]{2}{*}{ Species } & \multirow[b]{2}{*}{ Year } & \multicolumn{2}{|c|}{ Refugia } & \multicolumn{2}{|c|}{ Reference areas } \\
\hline & & Preharvest & Postharvest & Preharvest & Postharvest \\
\hline $\begin{array}{l}\text { Bobolink } \\
\text { (Dolichonyx } \\
\text { oryzivorus) }\end{array}$ & $\begin{array}{l}2014 \\
2015 \\
2016 \\
\text { mean }\end{array}$ & $\begin{array}{c}2.77(0.41) \\
1.50(0.43) \\
4.81(0.85) \\
3.03\end{array}$ & $\begin{array}{c}9.72(2.32) \\
3.57(2.19) \\
6.17(4.92) \\
6.49\end{array}$ & $\begin{array}{c}3.40(0.65) \\
0.46(0.46) \\
4.00(1.32) \\
2.62\end{array}$ & $\begin{array}{c}0.07(0.07) \\
0.00(0.00) \\
0.15(0.15) \\
0.07\end{array}$ \\
\hline $\begin{array}{l}\text { Grasshopper } \mathrm{S} \\
\text { (Ammodramus } \\
\text { savannarum) }\end{array}$ & $\begin{array}{r}\text { arrow } \\
2014 \\
2015 \\
2016 \\
\text { mean }\end{array}$ & $\begin{array}{c}0.44(0.24) \\
1.91(0.16) \\
1.69(0.52) \\
1.35\end{array}$ & $\begin{array}{c}1.61(0.68) \\
7.08(2.36) \\
5.30(1.57) \\
4.66\end{array}$ & $\begin{array}{c}0.35(0.26) \\
0.84(0.53) \\
1.75(0.40) \\
0.98\end{array}$ & $\begin{array}{c}0.08(0.08) \\
0.36(0.36) \\
0.60(0.39) \\
0.35\end{array}$ \\
\hline $\begin{array}{l}\text { Eastern Meado } \\
\text { (Sturnella } \\
\text { magna) }\end{array}$ & $\begin{array}{l}\text { lark } \\
2014 \\
2015 \\
2016 \\
\text { mean }\end{array}$ & $\begin{array}{c}0.15(0.09) \\
0.16(0.16) \\
0.47(0.29) \\
0.26\end{array}$ & $\begin{array}{c}0.23(0.16) \\
1.32(0.81) \\
0.33(0.20) \\
0.63\end{array}$ & $\begin{array}{c}0.47(0.33) \\
0.33(0.33) \\
0.08(0.08) \\
0.29\end{array}$ & $\begin{array}{c}0.74(0.27) \\
0.49(0.33) \\
0.48(0.48) \\
0.57\end{array}$ \\
\hline
\end{tabular}

For Bobolinks, the difference in abundance between refugia and reference areas was driven by reduced densities in reference areas postharvest ( 3 -yr mean: $97 \%$ decrease; mixed effect model, $\beta_{\text {pre vs. }}$ post $=2.96$ [1.54, 4.39]; Tables 2 and 3), and less so by increased densities in refugia (114\% increase; $\beta=-3.73[-7.97,0.50])$. Grasshopper Sparrow density both decreased in reference areas (65\% decrease; $\beta=0.66[0.22,1.11])$, and increased in refugia postharvest $(246 \%$ increase; $\beta=-2.95$ [-3.82, -2.09]). Eastern Meadowlark density remained at similar levels in both reference areas $(\beta=-0.30[-0.80,0.19])$ and refugia $(\beta=-0.21[-0.68,0.26])$ following the harvests.

\section{Refugia postharvest dynamics}

Greater length to width ratios were associated with higher relative Grasshopper Sparrow densities in refugia (general linear model, $\beta=0.52$ [95\% C.I.: $0.29,0.74] ; F_{1,56}=21.1, P<0.001$ ), but this factor was not predictive for any other species $\left(F_{1,56}=0.07-0.18\right.$, $P=0.67-0.79)$. The difference between refugia and reference areas increased for Eastern Meadowlark with days after harvest $(\beta=$ $\left.0.048[0.005,0.090] ; F_{1,56}=4.9, P=0.03\right)$, whereas Bobolink and Grasshopper Sparrow showed no change $\left(F_{1,56}=0.3-0.8, P=\right.$ $0.38-0.59)$. Grasshopper Sparrow usage varied by year, with higher relative densities in refugia postharvest in $2016\left(\beta_{2016}\right.$ vs. $\left.{ }_{2014}=3.22[1.55,4.90] ; F_{1,56}=14.8, P<0.001\right)$.

\section{Postharvest field abandonment}

Field-level densities of Bobolink on the two completely mowed fields averaged 1.1 individuals/ha (3-yr mean) before the harvest, dropping to zero afterward (100\% decline in all three years); Grasshopper Sparrow densities dropped an average of $83 \%$; Eastern Meadowlark dropped an average of $14 \%$ and showed less consistency among fields and years (Table 4). In the primary field that contained refugia, Bobolink densities dropped less steeply in all three years following harvest, by an average of 57\% (1.8 to $0.8 /$ ha), while Grasshopper Sparrow and Eastern Meadowlark densities both increased in all three years (Table 4).

Fig. 3. Grassland bird abundance in unharvested refugia and harvested reference areas before and after harvest within a 23ha hayfield in central New Jersey, USA. Points represent the average difference ( $\pm 2 \mathrm{SE}$ ) in density (individuals / ha) between refugia and reference areas, calculated before and after hay harvest ( $\mathrm{n}=5$ for each estimate). The dates of harvest were 26 Jun 2014, 31 Jul-3 Aug 2015, and 5-6 Jul 2016. A before-aftercontrol-impact paired series analysis revealed increased relative usage of refugia by Bobolink (Dolichonyx oryzivorous) and Grasshopper Sparrow (Ammodramus savannarum), but not Eastern Meadowlark (Sturnella magna).
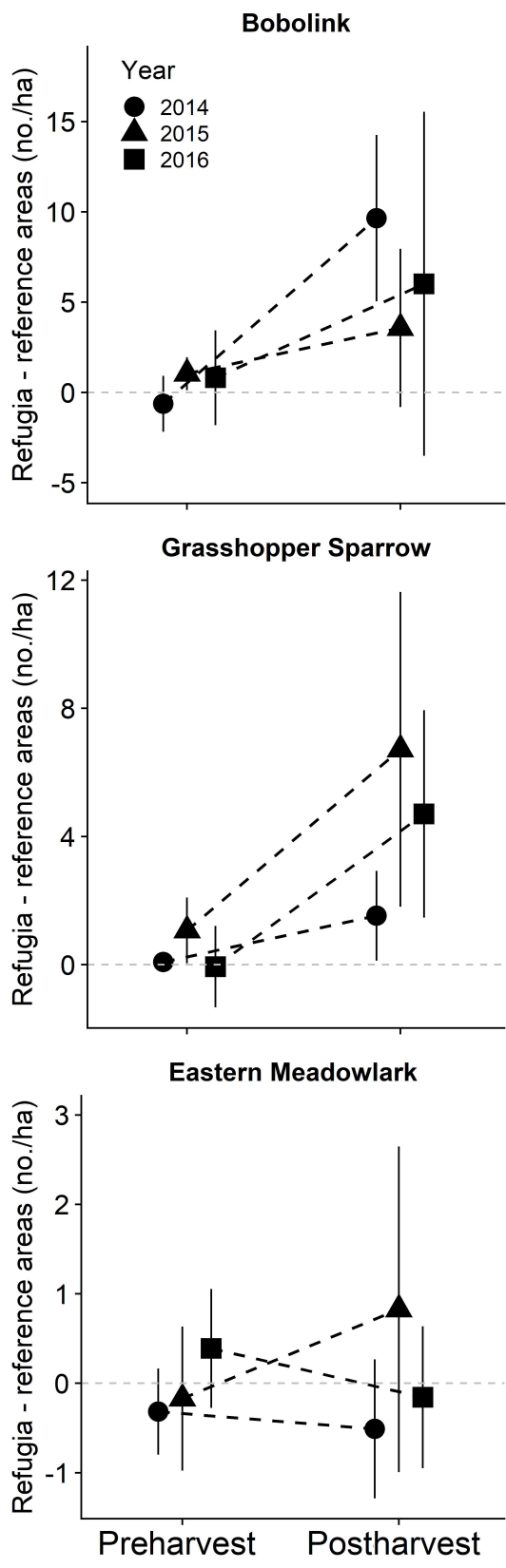
Table 3. Results of repeated-measures linear mixed models used to examine relative grassland bird use of uncut refugia and harvested reference areas (each 0.25 ha in size) in a New Jersey (USA) hayfield, 2014-2016. Bobolink (Dolichonyx oryzivorous); Grasshopper Sparrow (Ammodramus savannarum); Eastern Meadowlark (Sturnella magna).

\begin{tabular}{|c|c|c|c|c|c|c|c|c|c|c|c|}
\hline $\begin{array}{l}\text { Species / } \\
\text { Dependent Variable }\end{array}$ & $\begin{array}{l}\text { Independent } \\
\text { variables }\end{array}$ & $\begin{array}{l}\text { Coefficient } \\
(95 \% \text { C.I. })\end{array}$ & $\mathrm{F}$ & $\mathrm{df}$ & $P$ & $\begin{array}{l}\text { Species / } \\
\text { Dependent Variable }\end{array}$ & $\begin{array}{l}\text { Independent } \\
\text { variables }\end{array}$ & $\begin{array}{l}\text { Coefficient } \\
(95 \% \text { C.I. })\end{array}$ & $\mathrm{F}$ & $\mathrm{df}$ & $\mathrm{P}$ \\
\hline \multirow{3}{*}{$\begin{array}{l}\text { Bobolink / } \\
\Delta \text { density } \\
\text { (refugia-reference) }\end{array}$} & Intercept & $\begin{array}{c}7.86 \\
(3.51,12.20)\end{array}$ & & & & $\begin{array}{l}\text { Eastern Meadowlark / } \\
\Delta \text { density }\end{array}$ & Intercept & $\begin{array}{c}-0.46 \\
(-1.06,0.12)\end{array}$ & & & \\
\hline & $\begin{array}{l}\text { Year } \\
\text { (2015 vs. } 2014) \\
\text { Year } \\
(2016 \text { vs. } 2014)\end{array}$ & $\begin{array}{c}-2.20 \\
(-8.09,3.51) \\
-1.09 \\
(-5.73,3.68)\end{array}$ & 0.3 & $2 / 292$ & 0.75 & (refugia-reference) & $\begin{array}{l}\text { Year } \\
\text { (2015 vs. 2014) } \\
\text { Year } \\
\text { (2016 vs. 2014) }\end{array}$ & $\begin{array}{c}0.74 \\
(-0.14,1.59) \\
0.53 \\
(-0.16,1.23)\end{array}$ & 1.8 & $2 / 292$ & 0.17 \\
\hline & $\begin{array}{l}\text { Pre vs. } \\
\text { postharvest } \\
\text { Transect } \\
\text { (SD, rand. effect) }\end{array}$ & $\begin{array}{c}-6.70 \\
(-10.87,-2.44) \\
1.98 \\
(0.00,4.64)\end{array}$ & 9.6 & $1 / 292$ & 0.002 & & $\begin{array}{l}\text { Pre vs. } \\
\text { postharvest } \\
\text { Transect } \\
\text { (SD, rand. effect) }\end{array}$ & $\begin{array}{c}0.10 \\
(-0.53,0.72) \\
0.09 \\
(0.00,0.51)\end{array}$ & 0.1 & $1 / 292$ & 0.77 \\
\hline \multirow[t]{3}{*}{$\begin{array}{l}\text { Bobolink / } \\
\text { Density in refugia }\end{array}$} & Intercept & $\begin{array}{c}8.11 \\
(3.81,12.48)\end{array}$ & & & & $\begin{array}{l}\text { Eastern Meadowlark / } \\
\text { Density in refugia }\end{array}$ & Intercept & $\begin{array}{c}0.29 \\
(-0.13,0.73)\end{array}$ & & & \\
\hline & $\begin{array}{l}\text { Year } \\
(2015 \text { vs. } 2014) \\
\text { Year } \\
(2016 \text { vs. } 2014)\end{array}$ & $\begin{array}{c}-3.71 \\
(-9.28,1.90) \\
-0.75 \\
(-5.38,4.02)\end{array}$ & 0.8 & $2 / 292$ & 0.43 & 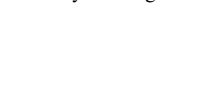 & $\begin{array}{l}\text { Year } \\
\text { (2015 vs. 2014) } \\
\text { Year } \\
(2016 \text { vs. } 2014)\end{array}$ & $\begin{array}{c}0.55 \\
(-0.08,1.18) \\
0.21 \\
(-0.30,0.73)\end{array}$ & 1.5 & $2 / 292$ & 0.23 \\
\hline & $\begin{array}{l}\text { Pre vs. } \\
\text { postharvest } \\
\text { Transect } \\
\text { (SD, rand. effect) }\end{array}$ & $\begin{array}{c}-3.73 \\
(-7.97,0.50) \\
2.15 \\
(0.00,4.86)\end{array}$ & 3.1 & $1 / 292$ & 0.08 & & $\begin{array}{l}\text { Pre vs. } \\
\text { postharvest } \\
\text { Transect } \\
\text { (SD, rand. effect) }\end{array}$ & $\begin{array}{c}-0.21 \\
(-0.68,0.26) \\
0.00 \\
(0.00,0.36)\end{array}$ & 0.8 & $1 / 292$ & 0.38 \\
\hline \multirow[t]{3}{*}{$\begin{array}{l}\text { Bobolink / } \\
\text { Density in reference }\end{array}$} & Intercept & $\begin{array}{c}0.25 \\
(-1.09,1.57)\end{array}$ & & & & $\begin{array}{l}\text { Eastern Meadowlark / } \\
\text { Density in reference }\end{array}$ & Intercept & $\begin{array}{c}0.75 \\
(0.23,1.29)\end{array}$ & & & \\
\hline & $\begin{array}{l}\text { Year } \\
(2015 \text { vs. } 2014) \\
\text { Year } \\
(2016 \text { vs. } 2014)\end{array}$ & $\begin{array}{c}-1.50 \\
(-3.50,0.49) \\
0.34 \\
(-1.28,1.96)\end{array}$ & 1.7 & $2 / 292$ & 0.18 & & $\begin{array}{l}\text { Year } \\
\text { (2015 vs. 2014) } \\
\text { Year } \\
\text { (2016 vs. } 2014)\end{array}$ & $\begin{array}{c}-0.19 \\
(-0.87,0.46) \\
-0.32 \\
(-0.89,0.22)\end{array}$ & 0.7 & $2 / 292$ & 0.51 \\
\hline & $\begin{array}{l}\text { Pre vs. } \\
\text { postharvest } \\
\text { Transect } \\
\text { (SD, rand. effect) }\end{array}$ & $\begin{array}{c}2.96 \\
(1.54,4.39) \\
0.00 \\
(0.00,1.11)\end{array}$ & 16.1 & $1 / 292$ & $<0.001$ & & $\begin{array}{l}\text { Pre vs. } \\
\text { postharvest } \\
\text { Transect } \\
\text { (SD, rand. effect) }\end{array}$ & $\begin{array}{c}-0.30 \\
(-0.80,0.19) \\
0.29 \\
(0.00,0.61)\end{array}$ & 1.5 & $1 / 292$ & 0.22 \\
\hline \multirow{2}{*}{$\begin{array}{l}\text { Grasshopper Sparrow / } \\
\Delta \text { density } \\
\text { (refugia-reference) }\end{array}$} & Intercept & $\begin{array}{c}2.61 \\
(1.09,4.12)\end{array}$ & & & & & & & & & \\
\hline & $\begin{array}{l}\text { Year } \\
\text { (2015 vs. 2014) } \\
\text { Year } \\
\text { (2016 vs. 2014) } \\
\text { Pre vs. } \\
\text { postharvest } \\
\text { Transect } \\
\text { (SD, rand. effect) }\end{array}$ & $\begin{array}{c}3.09 \\
(1.71,4.42) \\
1.52 \\
(0.41,2.61) \\
-3.61 \\
(-4.60,-2.63) \\
1.36 \\
(0.00,2.39)\end{array}$ & 10.5 & $2 / 292$ & $<0.001$ & & & & & & \\
\hline \multirow[t]{2}{*}{$\begin{array}{l}\text { Grasshopper Sparrow / } \\
\text { Density in refugia }\end{array}$} & Intercept & $\begin{array}{c}2.50 \\
(1.07,3.92)\end{array}$ & & & & & & & & & \\
\hline & $\begin{array}{l}\text { Year } \\
\text { (2015 vs. 2014) } \\
\text { Year } \\
\text { (2016 vs. 2014) } \\
\text { Pre vs. } \\
\text { postharvest } \\
\text { Transect } \\
\text { (SD, rand. effect) }\end{array}$ & $\begin{array}{c}3.47 \\
(2.26,4.65) \\
2.47 \\
(1.50,3.43) \\
-2.95 \\
(-3.82,-2.09) \\
1.37 \\
(0.14,2.39)\end{array}$ & 44.9 & $1 / 292$ & $<0.001$ & & & & & & \\
\hline \multirow[t]{2}{*}{$\begin{array}{l}\text { Grasshopper Sparrow / } \\
\text { Density in reference }\end{array}$} & Intercept & $\begin{array}{c}-0.11 \\
(-0.58,0.35)\end{array}$ & & & & & & & & & \\
\hline & $\begin{array}{l}\text { Year } \\
\text { (2015 vs. 2014) } \\
\text { Year } \\
\text { (2016 vs. 2014) } \\
\text { Pre vs. } \\
\text { postharvest } \\
\text { Transect } \\
\text { (SD, rand. effect) }\end{array}$ & $\begin{array}{c}0.39 \\
(-0.22,1.00) \\
0.95 \\
(0.44,1.45) \\
0.66 \\
(0.22,1.11) \\
0.22 \\
(0.00,0.51)\end{array}$ & 8.4 & $2 / 292$ & 0.004 & & & & & & \\
\hline
\end{tabular}

\section{Nesting phenology and harvest impact on nests}

We found a total of 26 nests of target species: 17 Bobolink (12 in primary, 5 in north/south fields), 6 Grasshopper Sparrow (2 in primary, 4 in north/south), and 3 Eastern Meadowlark (2 in primary, 1 in north/south). Prior to hay harvest, 13 nests fledged and 9 failed (Bobolink: 6 fail, 9 fledge; Grasshopper Sparrow: 2 fail, 3 fledge; Eastern Meadowlark: 1 fail, 1 fledge). Of the four nests still active during hay harvest events, 3 nests (2 Bobolink and 1 Grasshopper Sparrow nests) were destroyed by hay machinery, whereas the only nest still active in a refugium (1
Eastern Meadowlark nest) was spared and fledged young. No renesting was observed postharvest, but multiple Grasshopper Sparrow males were observed singing within the refugia. Based on estimated initiation dates and nest cycle lengths, $50 \%$ of the 26 nests monitored either fledged or would have fledged by 24 June, and $95 \%$ by 23 July. For Bobolink, the only species with adequate sample sizes, these dates were 21 June and 12 July.

\section{DISCUSSION}

We found increased use of refugia by Bobolinks and Grasshopper Sparrows relative to reference areas following the hay harvest (Fig. 3 ), suggesting that refugia are likely of value to these species. 
Table 4. Mean density (individuals / ha) before and after harvest in three adjacent hayfields in central New Jersey (USA): a "primary" field in which rectangular unharvested refugia were left, and two adjacent fields that lacked refugia ("north" and "south" fields; see Fig.2). Bobolink (Dolichonyx oryzivorous); Grasshopper Sparrow (Ammodramus savannarum); Eastern Meadowlark (Sturnellamagna).

\begin{tabular}{|c|c|c|c|c|c|c|c|c|c|c|}
\hline \multirow[b]{2}{*}{ Species } & \multirow[b]{2}{*}{ Year } & \multicolumn{3}{|c|}{$\begin{array}{l}\text { North Field } \\
\text { (no refugia) }\end{array}$} & \multicolumn{3}{|c|}{$\begin{array}{l}\text { South Field } \\
\text { (no refugia) }\end{array}$} & \multicolumn{3}{|c|}{$\begin{array}{c}\text { Primary Field } \\
\text { (5 refugia: } 5 \% \text { of area) }\end{array}$} \\
\hline & & $\begin{array}{l}\text { Density } \\
\text { Before } \\
\text { Harvest } \\
\text { (no./ha) }\end{array}$ & $\begin{array}{c}\text { Density } \\
\text { After } \\
\text { Harvest } \\
\text { (no./ha) }\end{array}$ & $\%$ change & $\begin{array}{l}\text { Density } \\
\text { Before } \\
\text { Harvest } \\
\text { (no./ha) }\end{array}$ & $\begin{array}{l}\text { Density } \\
\text { After } \\
\text { Harvest } \\
\text { (no./ha) }\end{array}$ & $\%$ change & $\begin{array}{l}\text { Density } \\
\text { Before } \\
\text { Harvest } \\
\text { (no./ha) }\end{array}$ & $\begin{array}{c}\text { Density } \\
\text { After } \\
\text { Harvest } \\
\text { (no./ha) }\end{array}$ & $\%$ change \\
\hline \multirow[t]{4}{*}{ Bobolink } & 2014 & 2.17 & 0 & $-100 \%$ & 1.12 & 0 & $-100 \%$ & 2.12 & 1.13 & $-47 \%$ \\
\hline & 2015 & 0.81 & 0 & $-100 \%$ & 0.30 & 0 & $-100 \%$ & 1.58 & 0.62 & $-60 \%$ \\
\hline & 2016 & $0^{\dagger}$ & $\mathrm{NA}^{\dagger}$ & $\mathrm{NA}^{\dagger}$ & 0.47 & 0 & $-100 \%$ & 1.71 & 0.62 & $-64 \%$ \\
\hline & Mean & 1.49 & 0 & $-100 \%$ & 0.63 & 0 & $-100 \%$ & 1.80 & 0.79 & $-57 \%$ \\
\hline Grasshopper & 2014 & 0.72 & 0.26 & $-64 \%$ & 0.29 & 0 & $-100 \%$ & 0.29 & 0.41 & $42 \%$ \\
\hline \multirow[t]{3}{*}{ Sparrow } & 2015 & 0.70 & 0.04 & $-94 \%$ & 0.45 & 0.06 & $-86 \%$ & 0.61 & 0.85 & $39 \%$ \\
\hline & 2016 & $0.30^{\dagger}$ & $\mathrm{NA}^{\dagger}$ & $\mathrm{NA}^{\dagger}$ & 0.60 & 0.17 & $-72 \%$ & 0.66 & 0.74 & $13 \%$ \\
\hline & Mean & 0.71 & 0.15 & $-79 \%$ & 0.45 & 0.08 & $-86 \%$ & 0.52 & 0.67 & $31 \%$ \\
\hline Eastern & 2014 & 0.05 & 0 & $-100 \%$ & 0.11 & 0.34 & $219 \%$ & 0.17 & 0.32 & $95 \%$ \\
\hline \multirow[t]{3}{*}{ Meadowlark } & 2015 & 0 & 0 & 0 & 0.08 & 0.04 & $-49 \%$ & 0.15 & 0.25 & $73 \%$ \\
\hline & 2016 & $0^{\dagger}$ & $\mathrm{NA}^{\dagger}$ & $\mathrm{NA}^{\dagger}$ & 0.07 & 0 & $-100 \%$ & 0.10 & 0.20 & $97 \%$ \\
\hline & Mean & 0.02 & 0 & $-50 \%$ & 0.08 & 0.13 & $23 \%$ & 0.14 & 0.26 & $88 \%$ \\
\hline
\end{tabular}

NA = Field planted in row crop (Sorghum Sudangrass) in 2016; this value not included in the mean.

Refugia may have reduced field abandonment as both Bobolinks and Grasshopper Sparrows decreased sharply following harvest in the completely-harvested fields, but less steeply or not at all in the primary field with refugia. In contrast, Eastern Meadowlarks did not show a change in relative use of refugia areas pre- vs. postharvest, and experienced a lower magnitude and consistency of field abandonment following harvest in the fields that lacked refugia. We observed no evidence of renesting in the refugia other than territorial singing by Grasshopper Sparrows, perhaps because hay harvests occurred relatively late in the breeding season (26 Jun-3 Aug).

Incentivized conservation management measures such as leaving unharvested refugia can be considered a "land sharing" approach in which agricultural production and biodiversity conservation coexist (Dotta et al. 2016). In other words, it is a method of reducing competing claims (economic vs. conservation) for grasslands to the benefit of both birds and farmers. Grassland birds may be particularly suited to such an approach in the northeastern U.S. because the alternative ("land sparing" or the creation of grassland protected areas) requires costly management to maintain habitats and could potentially shift intensive grassland agriculture elsewhere on the landscape with these fields continuing to function as ecological traps (Perlut et al. 2008, Seigel and Lockwood 2010). The cost of maintaining such grassland preserves may partly explain the disproportionately low representation of grassland birds in protected area networks of the northeastern U.S. (Stauffer et al. 2017). In Europe and increasingly elsewhere, comprehensive agri-environmental approaches integrating biodiversity into agricultural landscapes using a toolbox of species- or guild-specific conservation measures are gaining popularity (Perlut et al. 2011, Batáry et al. 2015). Our results suggest that such an approach in the U.S., and in particular in the northeast, may provide real conservation benefits to grassland birds.

We suggest that leaving refugia within active hayfields is a tool that could be used in concert with a suite of other management tactics for grassland birds in working landscapes such as row crop-to-grass conversion and whole-field delayed harvest programs (e.g., the Conservation Reserve Program [CRP]; Nocera et al. 2005, Troy et al. 2005). Although the populationlevel effects, i.e., increased carrying capacity and fecundity, may be less than with existing CRP-like programs, the economics of leaving refugia gives it the potential to affect a larger number of fields. Refugia in our study occupied only $5 \%$ of the field area and would therefore require compensation for a $~ 5 \%$ loss in revenue of first-cutting hay. Refugia, ideally centrally located (Renfrew et al. 2005), could then be harvested as part of a second cutting after the grassland bird nesting season. The low cost of implementation and flexibility for both conservation professionals and farmers may make it a viable option, especially where other approaches are not feasible.

\section{Bird use of refugia}

Our finding that Bobolink and Grasshopper Sparrow were more abundant in refugia vs. reference areas after harvest is encouraging because it shows that even small ( 0.25 ha) areas of longer grass can provide attractive habitat for these species compared with relatively bare cut areas. These results agree with a similar study in French hayfields that found Corn Crake (Crex crex) and Quail (Coturnix coturnix) densities increased $~ 2-6$ fold inside 10-m-wide uncut strips following harvest and documented several grassland passerines using the strips (Broyer 2003). Bobolink and Grasshopper Sparrow primarily eat seeds and foliar invertebrates (Vickery 1996, Renfrew et al. 2015), and thus the refugia in our study likely maintained foraging conditions at least at a minimum level required by those species. Seed availability and foliar, though not necessarily soil-dwelling, invertebrates have been shown to be lower in hayfields following harvests (Vickery et al. 2001, Zalik and Strong 2008). A discrepancy in the effects of mowing on above- and belowground invertebrates may have contributed to our finding that Eastern Meadowlark was not attracted to refugia but instead foraged in cut and uncut areas at about equal shares. This species 
generally feeds on invertebrates at or below the soil surface (Jaster et al. 2012), and other soil-probing species, e.g., European Starling (Sturnus vulgaris), actively avoid taller vegetation because of poor visibility of predators and prey items (Devereux et al. 2004). We observed both Bobolink and Grasshopper Sparrow feeding on seed heads in refugia (e.g., thistle [Cirsium arvense], foxtail [Setaria spp.]) that were absent in cut areas, as well as on Orthopterans and various caterpillar-like larvae. Eastern Meadowlarks were most commonly observed foraging on the ground, frequently in cut areas with short vegetation, but no prey items were identified.

\section{Refugia postharvest dynamics}

We hypothesized that the attractiveness of refugia to grassland birds might change with time following the harvest because the surrounding matrix regrew and/or the refugia were depleted of resources. However, Grasshopper Sparrow and Bobolink showed no change in their relative use with time postharvest. Eastern Meadowlarks increased their relative use of refugia over time, but the magnitude of the increase was relatively small: a slope of 0.05 , or a total change of $\sim 0.5$ individuals refugium ${ }^{-1}$ survey $^{-1}$ over the 6-week postharvest period. The reason for this change is unclear but could be due to seasonal shifts in diet or prey availability.

Grasshopper Sparrow relative density in refugia increased along a gradient of short and compact to long and narrow, i.e., low to high length:width ratios; however, Bobolink relative density did not. This may be explained by differences in territorial behavior between the species in the latter part of the breeding season. Longer features could theoretically accommodate more territorial individuals than more-compact ones as strip-like refugia can potentially stretch across multiple territories. Grasshopper Sparrows are multiple-brooded with a $\sim 90-\mathrm{d}$ breeding season extending into August, and so may have remained territorial during the late-season postharvest period of our study (Vickery 1996). In contrast, Bobolinks are typically singlebrooded and start to form loose postbreeding flocks by early- to mid-July (Renfrew et al. 2015; M. C. Allen, unpublished data). Our observations support this potential difference in territorial behavior between Grasshopper Sparrows and Bobolink late in the season, as $20 \%$ of the Grasshopper Sparrows we observed in August were singing males, whereas no male Bobolinks were singing at this time.

\section{Postharvest field abandonment}

The fact that our primary field containing refugia maintained a population (albeit reduced) of Bobolinks following harvest, while the two fields that were completely harvested did not in all three years (Table 4), suggests that the refugia promoted site persistence for this species. Hay harvest involves the removal of most plant biomass from the field and consequently represents a dramatic structural alteration and reduction in food for some species. Bobolinks are known to abandon early-mowed hayfields completely following harvest for at least two weeks, presumably because of these alterations (Bollinger et al. 1990, Perlut et al. 2006). Other grassland species, including Whinchat (Saxicola rubetra) in Switzerland, and Baird's Sparrow (Ammodramus bairdii) and Sprague's Pipit (Anthus spragueii) in the northern Great Plains, experience similarly high rates of field abandonment after hayfield mowing (Owens and Myres 1973, Grüebler et al. 2015). Perhaps most relevant to our study is that, in Switzerland, increasing the fraction of a hayfield that is left unharvested during the breeding season decreases the proportion of Whinchats abandoning that field (Grüebler et al. 2015).

However, not all species may be as sensitive to habitat changes associated with hay harvesting. Savannah Sparrows (Passerculus sandwichensis), for example, largely remained and renested in the stubble of cut hayfields in the Champlain Valley (Perlut et al. 2006) and were common on mowed hayfields and edges of cultivated fields in the Great Plains (Owens and Myres 1973). Patterns of field abandonment for Grasshopper Sparrow and Eastern Meadowlark in our study suggest possible intermediate levels of sensitivity. Whereas Grasshopper Sparrow decreased following harvest by an average of $83 \%$ in the completely mowed fields, Eastern Meadowlark only decreased by $14 \%$ and showed less consistent patterns among fields and years. Both species increased in abundance in the primary field each year following harvest, possibly because of immigration from harvested adjacent fields. Further study of within-season site fidelity following harvests, i.e., the continuum of $100 \%$ remaining to complete abandonment, could lead to further insights on habitat preferences, sensitivity to agricultural practices, and the potential utility of in-field conservation interventions such as refugia.

\section{Nesting phenology and harvest impact on nests}

The primary field in our study was harvested relatively late (26 June-3 August vs. the typical May-July; Perlut et al. 2006) because of prioritization of other tasks by the farmers. This likely led to lower renesting rates than would be expected following earlier (May or June) harvests. For example, Bollinger et al. (1990) noted that Bobolinks do not renest if failure occurs after 20 June, but they documented renesting within unharvested regions of the same hayfields by 5 of 12 pairs that failed because of an earlier June harvest (sizes of uncut areas not given). Similarly, in Vermont, fields harvested in May were more readily recolonized by Bobolinks than later-cut fields, an observation that inspired the creation of a novel conservation incentive program (Perlut et al. 2011). This program allows farmers a high-quality hay harvest before 2 June, and allows grassland birds time to resettle and raise a brood before a second harvest is permitted. Grasshopper Sparrow and Eastern Meadowlark have longer nesting seasons, but still are more likely to renest following earlier harvests because nest initiations of both species begin to taper off sharply in July (Vickery 1996, Jaster et al. 2012). In general, these factors speak to the importance of further investigations into the utility of refugia when harvests are carried out earlier in the season when birds may be most likely to use them for renesting.

Though refugia within harvested hayfields are isolated habitat islands potentially vulnerable to increased predation, previous studies indicate that nest survival in these areas is not necessarily lower. A study of artificial nests placed in irregularly shaped uncut patches in Vermont hayfields (mean: 0.3 ha) found only 1 in 29 was depredated (Masse et al. 2008). Whinchat nests in Switzerland spared during the harvest within $10 \times 10 \mathrm{~m}$ unharvested patches had similar survival to nests in late-harvested fields, and higher survival than those in early-harvested fields (Grüebler et al. 2012). Similar results have been shown for larger nonpasserines, with improved survival of eggs (Musters et al. 2001, Kragten et al. 2008) and precocial young (Broyer 2003) within small unharvested strips or patches, including some protected by 
temporary electric fencing (Koks and Visser 2002). Nevertheless, more research into area effects is needed. It is possible that fewer, larger refugia may be preferable to multiple smaller ones for biological as well as practical reasons, including ease of implementation.

\section{Limitations and future research}

Our study represents a first look at the benefits of intentionally leaving uncut refugia as a conservation measure for grassland birds in hayfields; however, more research is needed to assess its generality. First, although we demonstrated increased relative abundance in refugia, we did not measure seed and invertebrate resources or quantify foraging behavior. It is possible that some individuals used the refugia to take advantage of perches for singing and predator scanning, though based on the literature and our observations of actively foraging individuals we believe the refugia did provide food as well. Second, because of logistical constraints on the farmer, the harvest date during all three years of our study was later than the regional norm of mid-June (Bollinger et al. 1990, Perlut et al. 2006). Although our results provide information on a stage of the avian life cycle that is underrepresented in the literature (Marra et al. 2015), further study in early-harvested fields with refugia is needed to better understand the success of renesting attempts of these grassland birds. Finally, though a repeated pattern emerged in all three years, our study was limited in geographic scope. Replication across broader scales is needed to confirm and expand inference to other regions and species. Ideally, these studies would explore more realistic scenarios including nonrandom siting of refugia that considers the biology of the species, e.g., habitat preferences or edge avoidance, farmers' needs, and prior knowledge of bird use at the site. These considerations would help to maximize conservation benefits while minimizing the economic impact to farmers. We believe that leaving unharvested refugia, essentially a "partial delayed-mowing" approach, deserves further examination as a potential supplement to established conservation incentive programs that alter harvest timing. Such work would have the added benefit of illuminating basic ecological questions such as differences in habitat preferences and disturbance tolerance among species.

Responses to this article can be read online at: http://www.ace-eco.org/issues/responses.php/1457

\section{Acknowledgments:}

We thank the Township of Readington, Profeta Farms, and the following people for access to fields and help implementing the experimental design: M. Burjan, T. Stewart, J. Place, P. Profeta, $J$. \& R. Allen, E. Morgan Allen, and R. Kappus. J. Brown and $O$. Stringham improved manuscript clarity.

\section{LITERATURE CITED}

Askins, R. A., F. Chavez-Ramirez, B. C. Dale, C. A. Haas, J. R. Herkert, F. L. Knopf, and P. D. Vickery. 2007. Conservation of grassland birds in North America: understanding ecological processes in different regions. Ornithological Monographs 2007:1-46. https://doi.org/10.2307/40166905
Batáry, P., L. V. Dicks, D. Kleijn, and W. J. Sutherland. 2015. The role of agri-environment schemes in conservation and environmental management. Conservation Biology 29:1006-1016. https://doi.org/10.1111/cobi.12536

Bates, D., M. Mächler, B. Bolker, and S. Walker. 2015. Fitting linear mixed-effects models using Ime4. Journal of Statistical Software 67:1-48. https://doi.org/10.18637/jss.v067.i01

Bollinger, E. K., P. B. Bollinger, and T. A. Gavin. 1990. Effects of hay-cropping on eastern populations of the Bobolink. Wildlife Society Bulletin 18:142-150.

Broyer, J. 2003. Unmown refuge areas and their influence on the survival of grassland birds in the Saône valley (France). Biodiversity and Conservation 12:1219-1237. https://doi. org/10.1023/A:1023099901308

Buckland S. T., D. R. Anderson, K. P. Burnham, and J. L. Laake. 1993. Distance sampling: estimating abundance of biological populations. Chapman \& Hall, London, UK.

Buri, P., R. Arlettaz, and J.-Y. Humbert. 2013. Delaying mowing and leaving uncut refuges boosts orthopterans in extensively managed meadows: evidence drawn from field-scale experimentation. Agriculture, Ecosystems and Environment 181:22-30. https://doi. org/10.1016/j.agee.2013.09.003

Buri, P., J.-Y. Humbert, and R. Arlettaz. 2014. Promoting pollinating insects in intensive agricultural matrices: field-scale experimental manipulation of hay-meadow mowing regimes and its effects on bees. PLoS ONE 9(1):e85635. https://doi. org/10.1371/journal.pone.0085635

Conner, M. M., W. C. Saunders, N. Bouwes, and C. Jordan. 2016. Evaluating impacts using a BACI design, ratios, and a Bayesian approach with a focus on restoration. Environmental Monitoring and Assessment 188:1-14. https://doi.org/10.1007/s10661-016-5526-6

DeVault, T. L., J. L. Belant, B. F. Blackwell, J. A. Martin, J. A. Schmidt, L. W. Burger Jr., J. W. Patterson Jr. 2012. Airports offer unrealized potential for alternative energy production. Environmental Management 49:517-522. https://doi.org/10.1007/ s00267-011-9803-4

Devereux, C. L., C. U. McKeever, T. G. Benton, and M. J. Whittingham. 2004. The effect of sward height and drainage on Common Starlings Sturnus vulgaris and Northern Lapwings Vanellus vanellus foraging in grassland habitats. Ibis 146:115-122. https://doi.org/10.1111/j.1474-919X.2004.00355.X

Dixon, A. P., D. Faber-Langendoen, C. Josse, J. Morrison, and C. Loucks. 2014. Distribution mapping of world grassland types. Journal of Biogeography 41:2003-2019. https://doi.org/10.1111/ jbi. 12381

Dotta, G., B. Phalan, T. W. Silva, R. Green, and A. Balmford. 2016. Assessing strategies to reconcile agriculture and bird conservation in the temperate grasslands of South America. Conservation Biology 30:618-627. https://doi.org/10.1111/ cobi. 12635

Garibaldi, L. A., L. G. Carvalheiro, S. D. Leonhardt, M. A. Aizen, B. R. Blaauw, R. Isaacs, M. Kuhlman, D. Kleijn, A. M. Klein, C. Kremen, L. Morandin, J. Scheper, and R. Winfree. 2014. From research to action: enhancing crop yield through wild pollinators. 
Frontiers in Ecology and the Environment 12:439-447. https://doi. org/10.1890/130330

Grüebler, M. U., H. Schuler, P. Horch, and R. Spaar. 2012. The effectiveness of conservation measures to enhance nest survival in a meadow bird suffering from anthropogenic nest loss. Biological Conservation 146:197-203. https://doi.org/10.1016/j. biocon.2011.12.019

Grüebler, M. U., H. Schuler, R. Spaar, and B. Naef-Daenzer. 2015. Behavioural response to anthropogenic habitat disturbance: indirect impact of harvesting on Whinchat populations in Switzerland. Biological Conservation 186:52-59. https://doi. org/10.1016/j.biocon.2015.02.031

Jaster, L. A., W. E. Jensen, and W. E. Lanyon. 2012. Eastern Meadowlark (Sturnella magna), version 2.0. In A. F. Poole, editor. The birds of North America. Cornell Lab of Ornithology, Ithaca, New York, USA. https://doi.org/10.2173/bna.160

Kragten, S., J. C. Nagel, and G. R. De Snoo. 2008. The effectiveness of volunteer nest protection on the nest success of Northern Lapwings Vanellus vanellus on Dutch arable farms. Ibis 150:667-673. https://doi.org/10.1111/j.1474-919X.2008.00842.X

Koks, B. J., and E. G. Visser. 2002. Montagu's Harriers Circus pygargus in the Netherlands: does nest protection prevent extinction? Ornihologischer Anzeiger 41:159-166.

Luscier, J. D., and W. L. Thompson. 2009. Short-term responses of breeding birds of grassland and early successional habitat to timing of haying in northwestern Arkansas. Condor 111:538-544. https://doi.org/10.1525/cond.2009.080019

Marra, P. P., E. B. Cohen, S. R. Loss, J. E. Rutter, and C. M. Tonra. 2015. A call for full annual cycle research in animal ecology. Biology Letters 11:20150552. https://doi.org/10.1098/rsbl.2015.0552

Masse, R. J., A. M. Strong, and N. G. Perlut. 2008. The potential of uncut patches to increase the nesting success of grassland songbirds in intensively managed hayfields: a preliminary study from the Champlain Valley of Vermont. Northeastern Naturalist 15:445-452. https://doi.org/10.1656/1092-6194-15.3.445

Miller, D. L., E. Rexstad, L. Thomas, L. Marshall, and J. L. Laake. 2019. Distance sampling in R. Journal of Statistical Software 89:1-29. https://doi.org/10.18637/jss.v089.i01

Musters, C. J. M., M. Kruk, H. J. De Graaf, and W. J. Ter Keurs. 2001. Breeding birds as a farm product. Conservation Biology 15:363-369. https://doi.org/10.1046/j.1523-1739.2001.015002363. $\mathrm{x}$

New Jersey Department of Environmental Protection (NJDEP). 2015. NJDEP 2012 land uselland cover update. NJDEP, Trenton, New Jersey, USA. [online] URL: https://www.nj.gov/dep/gis/ lulc12c.html

Nocera, J. J., G. J. Parsons, G. R. Milton, and A. H. Fredeen. 2005. Compatibility of delayed cutting regime with bird breeding and hay nutritional quality. Agriculture, Ecosystems and Environment 107:245-253. https://doi.org/10.1016/j.agee.2004.11.001

Owens, R. A., and M. T. Myres. 1973. Effects of agriculture upon populations of native passerine birds of an Alberta fescue grassland. Canadian Journal of Zoology 51:697-713. https://doi. org/10.1139/z73-104
Perlut, N. G., A. M. Strong, and T. J. Alexander. 2011. A model for integrating wildlife science and agri-environmental policy in the conservation of declining species. Journal of Wildlife Management 75:1657-1663. https://doi.org/10.1002/jwmg.199

Perlut, N. G., A. M. Strong, T. M. Donovan, and N. J. Buckley. 2006. Grassland songbirds in a dynamic management landscape: behavioral responses and management strategies. Ecological Applications 16:2235-2247. https://doi.org/10.1890/1051-0761 (2006)016[2235:GSIADM]2.0.CO;2

Perlut, N. G., A. M. Strong, T. M. Donovan, and N. J. Buckley. 2008. Regional population viability of grassland songbirds: effects of agricultural management. Biological Conservation 141:3139-3151. https://doi.org/10.1016/j.biocon.2008.09.011

Peterjohn, B. G. 2003. Agricultural landscapes: can they support healthy bird populations as well as farm products? Auk 120:14-19. https://doi.org/10.1642/0004-8038(2003)120[0014:ALCTSH]2.0.CO;2

R Core Team. 2017. R: a language and environment for statistical computing. R Foundation for Statistical Computing, Vienna, Austria. [online] URL: https://www.r-project.org/

Ramankutty, N., A. T. Evan, C. Monfreda, and J. A. Foley. 2008. Farming the planet: 1. Geographic distribution of global agricultural lands in the year 2000. Global Biogeochemical Cycles 22:GB1003. https://doi.org/10.1029/2007gb002952

Renfrew, R., A. M. Strong, N. G. Perlut, S. G. Martin, and T. A. Gavin. 2015. Bobolink (Dolichonyx oryzivorus), version 2.0. In P. D. Rodewald, editor. The birds of North America. Cornell Lab of Ornithology, Ithaca, New York, USA. https://doi.org/10.2173/ bna.176

Renfrew, R. B., C. A. Ribic, and J. L. Nack. 2005. Edge avoidance by nesting grassland birds: a futile strategy in a fragmented landscape. Auk 122:618-636. https://doi.org/10.1093/auk/122.2.618

Seigel, A. B., and J. L. Lockwood. 2010. How increasing levels of private land enrollment in conservation agreements affect the population viability of grassland birds. Biodiversity and Conservation 19:2343-2357. https://doi.org/10.1007/s10531-010-9837-6

Stauffer, G. E., D. A. W. Miller, A. M. Wilson, M. Brittingham, and D. W. Brauning. 2017. Stewardship responsibility of Pennsylvania public and private lands for songbird conservation. Biological Conservation 213:185-193. https://doi.org/10.1016/j. biocon.2017.07.005

Troy, A. R., A. M. Strong, S. C. Bosworth, T. M. Donovan, N. J. Buckley, and M. L. Wilson. 2005. Attitudes of Vermont dairy farmers regarding adoption of management practices for grassland songbirds. Wildlife Society Bulletin 33:528-538. https:// doi.org/10.2193/0091-7648(2005)33[528:AOVDFR]2.0.CO;2

United States Department of Agriculture (USDA). 2012. Census of agriculture. USDA, Washington, D.C., USA. [online] URL: https://www.nass.usda.gov/AgCensus/

Vickery, J. A., J. R. Tallowin, R. E. Feber, E. J. Asteraki, P. W. Atkinson, R. J. Fuller, and V. K. Brown. 2001. The management of lowland neutral grasslands in Britain: effects of agricultural practices on birds and their food resources. Journal of Applied Ecology 38:647-664. https://doi.org/10.1046/j.1365-2664.2001.00626. $\mathrm{X}$ 
Vickery, P. D. 1996. Grasshopper Sparrow (Ammodramus savannarum), version 2.0. In A. F. Poole and F. B. Gill, editors. The birds of North America. Cornell Lab of Ornithology, Ithaca, New York, USA. https://doi.org/10.2173/bna.239

Winter, M., S. E. Hawks, J. A. Shaffer, and D. H. Johnson. 2003. Guidelines for finding nests of passerine birds in tallgrass prairie. Prairie Naturalist 35:198-211.

Zalik, N. J., and A. M. Strong. 2008. Effects of hay cropping on invertebrate biomass and the breeding ecology of Savannah Sparrows (Passerculus sandwichensis). Auk 125:700-710. https:// doi.org/10.1525/auk.2008.07106 